\section{Spat over IMI funding and intellectual property}

In March, the Innovative Medicines Initiative (IMI) launched its second wave of eight newly funded research projects with a $€ 172$ (\$242.7) million budget. The IMI's €2 (\$2.8) billion investment is Europe's largest public-private enterprise collaboration aimed at strengthening the continent's "competitiveness and innovativeness". Although purporting to "put small companies first," IMI's agenda has to a large extent been set by large pharmaceutical companies, with the European Commission (EC) providing funding for affiliated academic research (Nat. Biotechno/ 26, 717-718, 2008). But for many of the academic research institutions participating in the project, complaints are intensifying that IMI skews benefits too much in favor of large industry. Last September, for example, the League of European Research Universities (LERU) published a letter online (http://

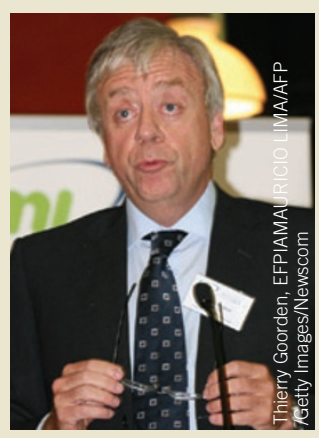

Michel Goldman, IMI Executive Director. www.leru.org/index.php/public/news/imi/) complaining that academic institutions participating in IMI projects lose money and are increasingly reluctant to take part.

The IMI is funded jointly by the EC and the European Federation of Pharmaceutical Industry Associations in Brussels-industry is required to at least match EC funding, in cash or in-kind. The initiative aims to develop tools and technologies to facilitate drug discovery. The scope of the newly funded projects is broad: from oncology biomarkers to software platforms and detection assays (see Table 1 ). The next wave of IMI funded projects will be announced later this year and a fourth wave soon after.

For an academic partner, IMI funds cover only $75 \%$ of direct projects costs and $20 \%$ of indirect project costs, which results in loss-making projects. This diverges from the EU's Framework Programme 7 , which covers $100 \%$ of direct costs and $60 \%$ of indirect costs-a disincentive to participate

Moreover, IMI's intellectual property agreement heavily favors the industrial partner's financial interests, says Michael Browne, head of European Research and Development at University College, London. For instance, the agreement would enable industry partners' affiliates to exploit any technology developed during an IMI project, without having to consult the research consortium, says Browne. Normally academic partners would require companies to list specific affiliates in the agreement to limit this knowledge sharing. "The wording of the IP policy is ambiguous as well," he adds. It assumes that academic partners would just sign over any knowledge they bring into the project.

The end result is that the academic institutions "get short shrift from both ends," he says. The fallout is that research institutions are increasingly leery of participating in IMI. University College London now requires any researcher who wants to participate in an IMI project to show how they intend to make up the funding gap. Both Oxford University and King's College, London, in addition to several European universities, have similar policies in place, says Browne.

The IP issues raised in the LERU letter were addressed by a IMI working group, and last November the IMI published a new IP Guidance Note (http://www.imi.europa.eu/ content/intellectual-property-policy) and several documents clarifying IP terms. IMI has also appointed, Kim DeRijck, as a representative to ensure academics should not feel disadvantaged when engaging in IP negotiations. Sarah Black, at IMI external relations, says IMI has noted no lack of applicants for IMI research grants.

Table 1 IMI $2^{\text {nd }}$ phase projects

\begin{tabular}{ll}
\hline Projects & Description \\
\hline OncoTrack & Discovery of tumor biomarkers that predict drug responses \\
\hline PREDECT & Optimization of in vitro and in vivo models of human cancer \\
\hline QuIC-ConCePT & Standardize and qualify imaging tumor biomarkers \\
\hline EHR4CR, DDMoRe and Open-PHACTS & Development of new software platforms and data sharing \\
\hline BTCure & $\begin{array}{l}\text { Development of methods to differentiate rheumatoid arthritis (RA) } \\
\text { and RA-like diseases }\end{array}$ \\
\hline RAPP-ID & $\begin{array}{l}\text { Development of point of care technology to detect bacteria, fungi, } \\
\text { viruses and biological markers of infection }\end{array}$
\end{tabular}

\section{IN brief}

\section{Monsanto dips into algae}

Monsanto acquired a stake in Sapphire Energy, a San Diego-based algae fuel company known for its prominent backers, including Bill Gates's firm Cascade Investment, in Kirkland, Washington, and the Wellcome Trust, in London. Through the deal (figures were not disclosed), the St. Louis agriculture giant gains access to Sapphire's expertise and technology for isolating algal traits that could be applied to agricultural genetic research. Algae share photosynthetic pathways with agricultural plants but their shorter life cycles speed up testing. That should allow the partnership to complete analyses of genetic traits in less than five days, according to Monsanto spokesperson Kelli Powers. "We're interested in gene leads that could ultimately help accelerate our yield-and-stress platform," Powers adds. Because green algae are singlecelled, says plant biologist Wim Vermaas of Arizona State University in Tempe, they will be useful for examining traits that shape plantwide factors such as photosynthesis or heat resistance-something harder to do in yeast or fungi model systems. Algae are less useful for studying signals that determine the height of a corn stalk or the way its roots develop, as they lack the necessary intracellular machinery. Algae could also be used in livestock feed, Vermaas says. Sapphire, like other algae biofuels firms, is also on the lookout for alternative revenue streams, its CEO Jason Pyle told Biofuels Digest, and Monsanto may offer those. Lucas Laursen

\section{Bayer's GM rice defeat}

In a lawsuit over genetically modified (GM) modified rice, jury members in an Arkansas circuit court ruled in March in favor of Riceland Foods of Stuttgart, Arkansas, a rice milling and exporting company, and against Bayer CropScience of Research Triangle Park, North Carolina, and Monheim, Germany. The jury recommended that Bayer pay Riceland $\$ 136.8$ million-\$125 million in punitive damages and $\$ 11.8$ million in compensatory damagescalling Bayer negligent for allowing traces of its genetically engineered Liberty Link, herbicide-tolerant experimental rice to mix with commercial lots of long grain rice in 2006. Back then, Mike Johans, then secretary of the US Department of Agriculture, said: "There are no human health, food safety or environmental concerns associated with this [GM Liberty Link] rice." Nonetheless, Riceland brought suit, claiming "loss of the European Union market," which cost it $\$ 380$ million in potential sales. Bayer counters that rice then destined for Europe "accounted for less than 5\% of USgrown rice," and "quickly was diverted and sold in other markets." The company, which also points out that the jury-recommended award "exceeds what is permitted by Arkansas law and will therefore be limited to the statutory cap of $\$ 1$ million," says it will consider whether to appeal after the court issues its final rulings. Meanwhile, Liberty Link rice, which was not commercialized, is no longer being developed.

Jeffrey $L$ Fox 